Article

\title{
Growth, Toxin Production and Allelopathic Effects of Pseudo-nitzschia multiseries under Iron-Enriched Conditions
}

\author{
Bruna Fernanda Sobrinho ${ }^{1}$, Luana Mocelin de Camargo ${ }^{1}$, Leonardo Sandrini-Neto ${ }^{1}$, \\ Cristian Rafael Kleemann ${ }^{2}$, Eunice da Costa Machado ${ }^{3}$ and Luiz Laureno Mafra Jr. ${ }^{1, *}$ \\ 1 Centro de Estudos do Mar, Universidade Federal do Paraná, P.O. Box 1, Pontal do Paraná 83255-976, PR, \\ Brazil; brunafernanda.sob@gmail.com (B.F.S.); lumocelin@gmail.com (L.M.d.C.); \\ leonardosandrini@gmail.com (L.S.-N.) \\ 2 Instituto Federal de Santa Catarina, Av. Abraão João Francisco, 3899, Itajaí 88307-303, SC, Brazil; \\ cristian.kleemann@gmail.com \\ 3 Instituto de Oceanografia, Universidade Federal do Rio Grande, Av. Itália, km 8, Carreiros, \\ Rio Grande 96203-900, RS, Brazil; eunice.ufpr@gmail.com \\ * Correspondence: luiz.mafra@ufpr.br; Tel.: +55-41-3511-8669; Fax: +55-41-3511-8648
}

Received: 26 August 2017; Accepted: 21 October 2017; Published: 24 October 2017

\begin{abstract}
In order to assess the effects of Fe-enrichment on the growth and domoic acid (DA) production of the toxigenic diatom Pseudo-nitzschia multiseries, static cultures that received the addition of different iron (Fe) concentrations were maintained for 30 days. Intra- and extracellular DA concentrations were evaluated over time, and growth and chain-formation were compared to those of non-toxic diatoms, Bacillaria sp. Growth rates of P. multiseries $\left(\mu=0.45-0.73 \mathrm{~d}^{-1}\right)$ were similar among cultures containing different Fe concentrations. Likewise, the similar incidence and length of $P$. multiseries stepped cell chains (usually $2-4$; up to 8 -cell long) among the treatments reinforces that the cultures were not growth-inhibited under any condition tested, suggesting an efficient Fe acquisition mechanism. Moreover, DA concentrations were significantly higher under the highest Fe concentration, indicating that Fe is required for toxin synthesis. Bacillaria sp. reached comparable growth rates under the same Fe concentrations, except when the dissolved cell contents from a P. multiseries culture was added. The 50-70\% reduction in cell density and 70-90\% decrease in total chlorophyll- $a$ content of Bacillaria sp. at early stationary growth phase indicates, for the first time, an allelopathic effect of undetermined compounds released by Pseudo-nitzschia to another diatom species.
\end{abstract}

Keywords: harmful algae; toxic diatoms; domoic acid; phycotoxins; allelopathy; iron fertilization

\section{Introduction}

The first episode of human intoxication associated with compounds produced by diatoms was recorded in 1987 in Cardigan Bay estuary, Prince Edward Island, Canada [1]. At that time, a bloom of the pennate diatom Pseudo-nitzschia multiseries caused the hospitalization of $>100$ people (4 deaths) who had consumed mussels contaminated with a neurotoxin identified as domoic acid (DA) [1,2]. Since then, anomalously high DA concentrations have been related to mortalities of the marine fauna in different coastal regions (e.g., [3-5]).

The neurotoxin DA is the causative agent of amnesic shellfish poisoning (ASP) in humans upon consumption of contaminated shellfish [6]. Although outbreaks of human poisoning by DA are not commonplace, many contamination incidents might not be adequately reported. The symptomatology and the rapid elimination of DA from the body make it difficult to clinically verify the intoxication [7]. 
During a bloom of Pseudo-nitzschia australis in 2014 at Galician coastal waters (Spain), for instance, two people reported symptoms of ASP (confusion and memory loss) after consumption of cooked mussels [8].

Pseudo-nitzschia spp. are common and abundant components of the coastal phytoplankton assemblage across the globe [9]. Although many authors (e.g., Wells et al. [10]) believe that all Pseudo-nitzschia species could become toxigenic under specific environmental conditions, only 26 out of $\sim 45$ described Pseudo-nitzschia species have been confirmed as DA producers so far [11]. Toxin production is greatly variable, depending on the species, strain, and physiological condition of the population [12,13]. Hence, the occurrence of Pseudo-nitzschia spp. at moderate to high cell abundance is not always coupled with the contamination of filter-feeding organisms with unsafe DA levels (e.g., Mafra et al. [14]).

As assessed by both field and laboratory studies, several environmental variables may stimulate DA production by these diatoms, including changes in the photoperiod [15,16], $\mathrm{pH}$ [17], salinity [18], temperature [19], and the availability of macronutrients, like silicon (Si), phosphorus $(\mathrm{P})[20,21]$ and nitrogen $(\mathrm{N})[22,23]$, and micronutrients such as copper $(\mathrm{Cu})$ and iron $(\mathrm{Fe})[6,10,24-26]$.

Iron is an essential trace element to the metabolism of primary producers, critical in the processes of photosynthesis, respiration, nitrogen reduction and fixation [27]. In marine environments, the fraction of Fe available for biological incorporation varies according to the dominant chemical forms, the preferences of phytoplankton cells for some of these, the balance between the reaction kinetics of Fe exchange among chemical species, and the mechanisms of Fe capture, specific to each species of phytoplankton [28]. According to the on-deck incubation experiments by Endo et al. [29], the addition of Fe would induce the formation of diatom blooms, demonstrating that growth of diatoms can be eventually limited by low Fe availability in seawater.

One of the possible ecological roles of DA is to chelate micronutrients like $\mathrm{Fe}$ and $\mathrm{Cu}[6,10,25]$, as suggested by the presence of three carboxyl groups in its chemical structure [24]. At high concentrations, DA is able to compete with other organic binders for the capture of dissolved Fe [6]. At lower levels, the toxin facilitates micronutrient absorption by increasing the exchange rates between ligands in solution and on the cell surface [30]. Thus, DA-producing diatoms might have developed more effective strategies for the acquisition of dissolved Fe relative to other phytoplankton species [10], enabling them to grow efficiently in seawater even under limiting conditions of this important micronutrient [6]. However, several aspects related to the mechanisms of DA synthesis, as well as the possible role of DA in conferring P. multiseries a competitive advantage under limiting $\mathrm{Fe}$ concentrations, must be better understood in order to assess the real ecological relevance of this toxin.

The present study combines a series of laboratory experiments with the aim of evaluating (i) the influence of increasing bioavailable Fe concentrations on the growth and toxin production by P. multiseries; and (ii) the possible role of DA in facilitating Fe acquisition by both P. multiseries and a non-toxigenic, chain former pennate diatom, Bacillaria sp. (Bacillariaceae), under low Fe concentrations. The possible negative effects of compounds produced by P. multiseries (i.e., allelopathy) on Bacillaria sp. growth were additionally assessed. Cell abundance, chain formation, and intra- and extracellular toxin levels were quantified over time in static cultures, and compared across the different experimental treatments.

\section{Results}

\subsection{Experiment 1: Pseudo-nitzschia multiseries}

\subsubsection{Growth}

The exponential growth rate of $P$. multiseries, measured between days 0 and 8 of the experiment $\left(\mu_{0-8}\right.$, avg \pm std $)$ was higher in the $+11,700 \mathrm{nmol} \mathrm{Fe} \cdot \mathrm{L}^{-1}\left("+11,700 \mathrm{Fe}^{\prime \prime}\right)$ treatment $\left(\mu_{0-8}=0.36 \pm\right.$ $\left.0.02 \mathrm{~d}^{-1}\right)$ compared to all other treatments $\left(\mu_{0-8}=0.25-0.31\right)$ (Table 1$)$. Conversely, cultures reached greater maximum cell densities in the $+1.7 \mathrm{Fe}$ treatment $\left(87,412 \pm 8592 \mathrm{cell} \cdot \mathrm{mL}^{-1}\right.$ on the 14 th day $)$ 
relative to the other treatments, where $P$. multiseries attained from $71,212 \pm 9132 \mathrm{cell} \cdot \mathrm{mL}^{-1}$ (in $+0 \mathrm{Fe}$ ) to $74,962 \pm 10,699$ cell $\cdot \mathrm{mL}^{-1}$ (in $+11,700 \mathrm{Fe}$ ) after $11-17$ days (Figure 1 ). For both growth rate and cell density, however, average values were not significantly different among treatments (see Supplementary Table S1 for statistics).

Table 1. Exponential growth rate between days 0 and 8 of culture $\left(\mu_{0-8}\right)$ and maximum growth rate $(\mu)$ (mean \pm standard error) for Pseudo-nitzschia multiseries $(n=4)$ and Bacillaria sp. $(n=3)$, exposed to cultures that received the addition of distinct iron concentrations $\left(\mathrm{nmol} \cdot \mathrm{L}^{-1}\right):+0 \mathrm{Fe} ;+1.7 \mathrm{Fe} ;+10 \mathrm{Fe}$; and $+11,700 \mathrm{Fe}$. For Bacillaria sp., an extra treatment $(+1.7 \mathrm{Fe}+\mathrm{Psm})$ was created with the addition of $1.7 \mathrm{nmol} \mathrm{Fe} \cdot \mathrm{L}^{-1}$ and the dissolved cell contents from a P. multiseries culture containing $52 \mathrm{ng} \mathrm{DA} \cdot \mathrm{mL}^{-1}$ and other undetermined compounds. DA: domoic acid.

\begin{tabular}{ccccc}
\hline \multirow{2}{*}{ Treatments } & \multicolumn{2}{c}{$\boldsymbol{P .}$ multiseries } & \multicolumn{2}{c}{ Bacillaria sp. } \\
\cline { 2 - 5 } & $\mu_{0-8}$ & $\mu$ & $\mu_{0-8}$ & $\mu$ \\
\hline$+0 \mathrm{Fe}$ & $0.25( \pm 0.05)$ & $0.74( \pm 0.05)$ & $0.28( \pm 0.02)$ & $0.81( \pm 0.05)$ \\
$+1.7 \mathrm{Fe}$ & $0.28( \pm 0.02)$ & $0.65( \pm 0.06)$ & $0.30( \pm 0.01)$ & $0.91( \pm 0.04)$ \\
$+1.7 \mathrm{Fe}+\mathrm{Psm}$ & $\mathrm{N} / \mathrm{A} *$ & $\mathrm{~N} / \mathrm{A}$ & $0.13( \pm 0.02)$ & $0.36( \pm 0.03)$ \\
$+10 \mathrm{Fe}$ & $0.31( \pm 0.01)$ & $0.54( \pm 0.03)$ & $0.36( \pm 0.02)$ & $0.80( \pm 0.16)$ \\
$+11,700 \mathrm{Fe}$ & $0.36( \pm 0.02)$ & $0.71( \pm 0.09)$ & $0.41( \pm 0.01)$ & $1.25( \pm 0.02)$ \\
\hline
\end{tabular}

* N/A: not applicable.
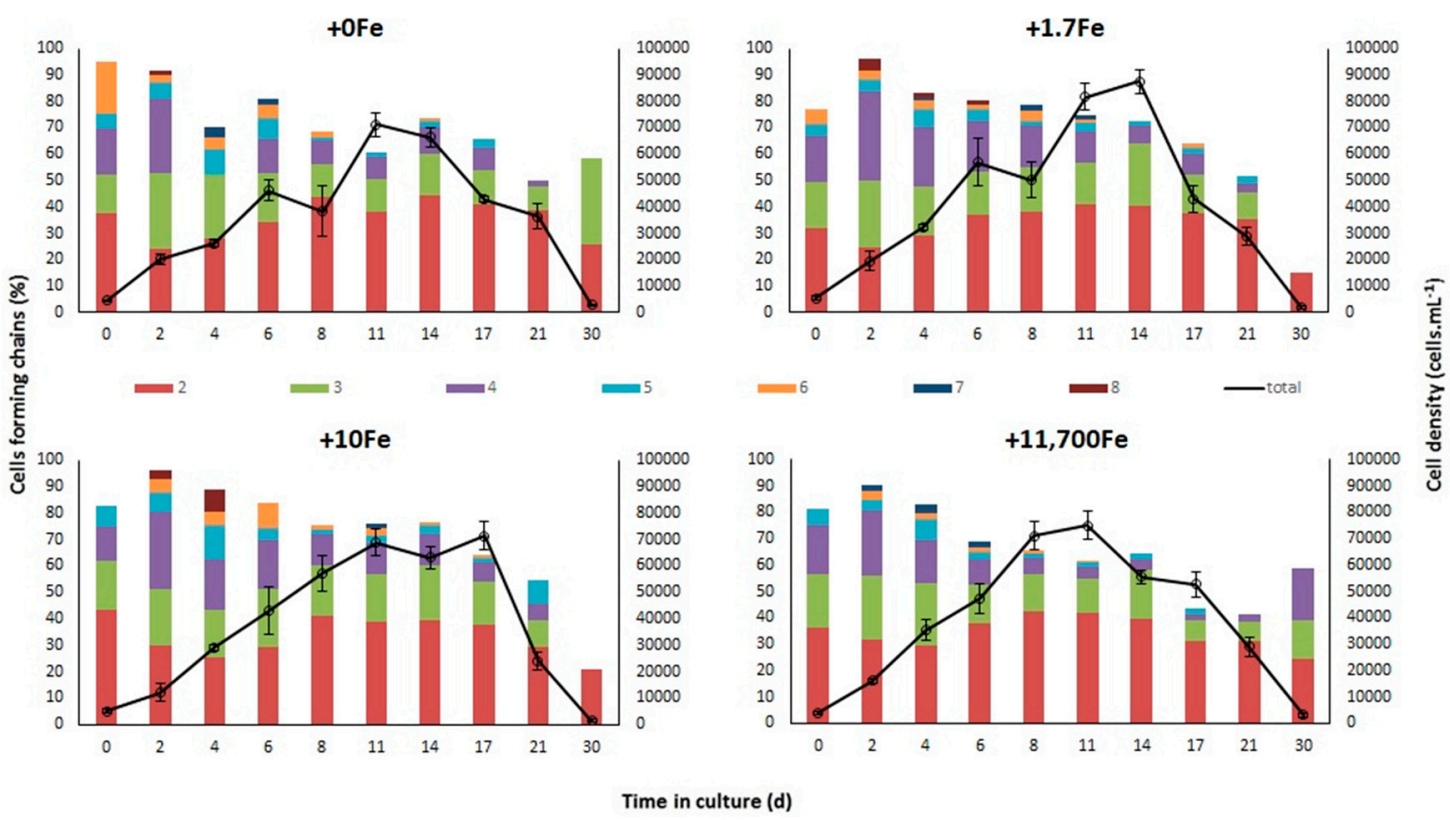

Figure 1. Average ( \pm standard error) cell density (solid line, $n=4)$ and percentage of cells forming chains of 2 to 8 cells throughout the growth cycle of Pseudo-nitzschia multiseries in static cultures that received the addition of distinct iron concentrations: $+0 \mathrm{Fe} ;+1.7 \mathrm{Fe} ;+10 \mathrm{Fe}$; and $+11,700 \mathrm{Fe} \mathrm{nmol} \cdot \mathrm{L}^{-1}$. Colors of the stacked bars represent different cell chain lengths.

In all treatments, P. multiseries formed linear chains of up to eight cells. Both the percentage of cells forming chains and the average number of cells per chain decreased gradually throughout the growth cycle, with no significant differences among the experimental treatments. In general, short chains with 2-4 cells predominated in all cultures (Figure 1).

There was a very strong relationship between $P$. multiseries cell densities and experiment days for each Fe addition treatment (Deviance explained = 92.7\%; Figure 2). Expected densities from generalized additive models (GAMs) reached maximum values at $\sim 11$ days after the beginning of the experiment 
in all treatments. However, the shapes of the smoother curves as well as the maximum expected density values varied among treatments. Expected cell densities were significantly higher in the $+1.7 \mathrm{Fe}$ treatment (Figure 2) than in other treatments receiving the addition of different Fe concentrations.
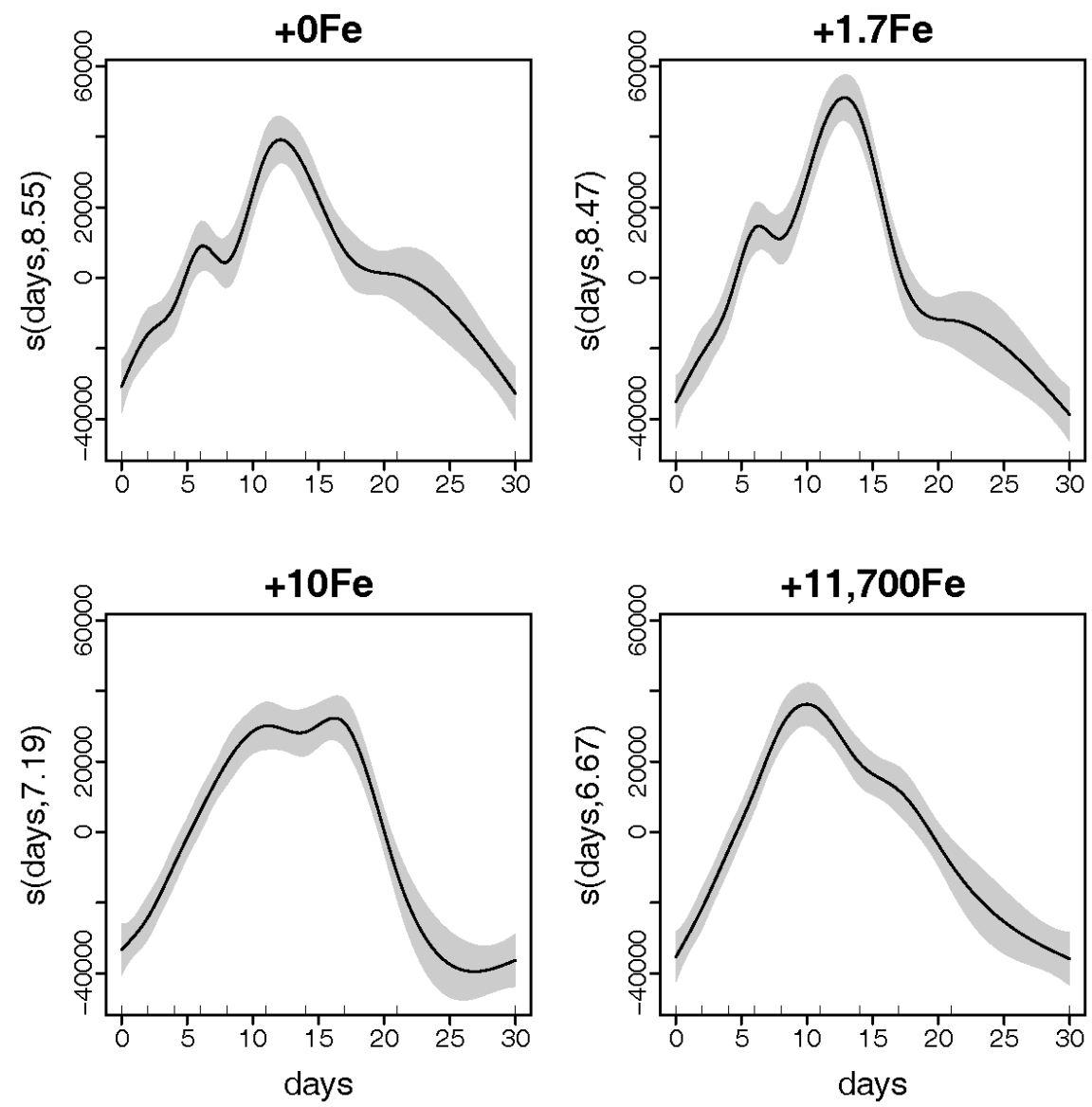

Figure 2. Estimated smoothing curves showing the relationship (solid line) between Pseudo-nitzschia multiseries densities and days for each Fe-enrichment treatment level: $+0 \mathrm{Fe} ;+1.7 \mathrm{Fe}$; $+10 \mathrm{Fe}$; and $+11,700 \mathrm{Fe} \mathrm{nmol} \cdot \mathrm{L}^{-1}$. Shaded area represents the standard error of the smooth curve. The rug plots on the $x$-axis indicate the days measurements were taken. Numbers after the variable name on the $y$-axis represent estimated degrees of freedom.

\subsubsection{Domoic Acid}

The intracellular, particulate DA concentrations (pDA) increased significantly over time $\left(p=2.2 \times 10^{-16}\right)$, and were significantly affected by the experimental treatments $\left(p=4.5 \times 10^{-4}\right)$. Greater pDA values were measured upon the highest addition of Fe $\left(11,700 \mu \mathrm{mol} \cdot \mathrm{L}^{-1}\right)$ compared to the other treatments, as recorded on days 8 and 17 (0.20-0.45 vs. $0.03-0.27 \mathrm{pg} \cdot$ cell $^{-1}$, respectively), and especially on day 30, when the highest intracellular levels were reported in all treatments

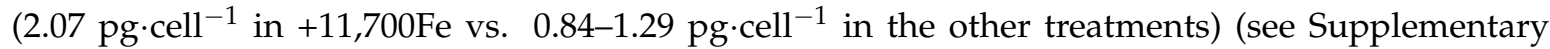
Table S2 for statistical results).

The extracellular, dissolved DA concentrations (dDA), also increased significantly along the growth curve $\left(p=5.4 \times 10^{-9}\right)$, but, in general, did not vary consistently across the experimental treatments $(p=0.39)$ when accounted on a per cell basis. At exponential growth (day 8$)$, the treatment without $\mathrm{Fe}$ addition yielded a higher mean $\mathrm{dDA}$ value $\left(1.85 \mathrm{pg} \cdot \mathrm{cell}^{-1}\right)$ relative to the other treatments $\left(0.55-0.81 \mathrm{pg} \cdot \mathrm{cell}^{-1}\right)$. In contrast, during the stationary phase (day 17), the highest dDA concentrations were measured in the treatment that received the highest Fe addition (91.3 vs. $1.95-25.8 \mathrm{pg} \cdot \mathrm{cell}^{-1}$ ). Later on, during the decline phase (day 30), the highest dDA values were again detected in the 
treatment without Fe addition (18.6 vs. 4.56-7.24 pg.cell ${ }^{-1}$ ) (Table 2). Concentrations of dDA were greater on day 17 compared to all other sampling days (Supplementary Table S2).

Table 2. Average ( \pm standard error; $n=4)$ intracellular $\left(\mathrm{pg} \cdot \mathrm{cell}^{-1}\right)$, extracellular $\left(\mathrm{pg} \cdot \mathrm{cell}^{-1}\right)$, and total $\left(\mu \mathrm{g} \cdot \mathrm{mL}^{-1}\right)$ domoic acid (DA) concentration throughout the growth cycle of Pseudo-nitzschia multiseries in cultures that received the addition of distinct iron concentrations $\left(\mathrm{nmol} \cdot \mathrm{L}^{-1}\right):+0 \mathrm{Fe} ;+1.7 \mathrm{Fe} ;+10 \mathrm{Fe}$; and $+11,700 \mathrm{Fe}$. Only living cells were considered for the calculation of cell density and intracellular DA concentration, while the sum of live and dead cells was used for the calculation of extracellular DA concentration.

\begin{tabular}{|c|c|c|c|c|}
\hline \multirow{2}{*}{ Days } & \multirow{2}{*}{ Treatments } & \multicolumn{3}{|c|}{ DA Concentration } \\
\hline & & Intracellular (pg.Cell-1) & Extracellular (pg.Cell ${ }^{-1}$ ) & Total $\left(\mu \mathrm{g} \cdot \mathrm{mL}^{-1}\right)$ \\
\hline \multirow{4}{*}{4} & $+0 \mathrm{Fe}$ & $0.04(0.001)$ & $0.44(0.07)$ & $0.01(0.001)$ \\
\hline & $+1.7 \mathrm{Fe}$ & $0.03(0.001)$ & $0.54(0.09)$ & $0.02(0.002)$ \\
\hline & $+10 \mathrm{Fe}$ & $0.04(0.005)$ & $0.72(0.17)$ & $0.02(0.008)$ \\
\hline & $+11,700 \mathrm{Fe}$ & $0.04(0.005)$ & $0.74(0.20)$ & $0.03(0.007)$ \\
\hline \multirow{4}{*}{8} & $+0 \mathrm{Fe}$ & $0.06(0.01)$ & $1.85(1.02)$ & $0.05(0.02)$ \\
\hline & $+1.7 \mathrm{Fe}$ & $0.06(0.02)$ & $0.81(0.49)$ & $0.03(0.001)$ \\
\hline & $+10 \mathrm{Fe}$ & $0.03(0.006)$ & $0.74(0.18)$ & $0.04(0.01)$ \\
\hline & $+11,700 \mathrm{Fe}$ & $0.20(0.02)$ & $0.55(0.08)$ & $0.04(0.008)$ \\
\hline \multirow{4}{*}{17} & $+0 \mathrm{Fe}$ & $0.26(0.06)$ & $1.95(1.11)$ & $0.10(0.05)$ \\
\hline & $+1.7 \mathrm{Fe}$ & $0.27(0.07)$ & $25.8(16.7)$ & $1.15(0.65)$ \\
\hline & $+10 \mathrm{Fe}$ & $0.14(0.03)$ & $2.15(1.05)$ & $0.18(0.08)$ \\
\hline & $+11,700 \mathrm{Fe}$ & $0.45(0.11)$ & $91.3(38.5)$ & $4.75(1.88)$ \\
\hline \multirow{4}{*}{30} & $+0 \mathrm{Fe}$ & $0.84(0.31)$ & $18.6(11.5)$ & $0.66(0.34)$ \\
\hline & $+1.7 \mathrm{Fe}$ & $1.21(0.37)$ & $4.56(1.95)$ & $0.20(0.08)$ \\
\hline & $+10 \mathrm{Fe}$ & $1.29(0.42)$ & $7.24(5.50)$ & $0.21(0.14)$ \\
\hline & $+11,700 \mathrm{Fe}$ & $2.07(1.25)$ & $6.83(2.51)$ & $0.28(0.11)$ \\
\hline
\end{tabular}

\subsection{Experiment 2: Bacillaria sp.}

\subsubsection{Growth}

Bacillaria sp. attained up to $30,500 \pm 5007$ cell $\cdot \mathrm{mL}^{-1}$ in treatment $+10 \mathrm{Fe}, 26,850 \pm 2333 \mathrm{cell} \cdot \mathrm{mL}^{-1}$ in treatment $+11,700 \mathrm{Fe}, 24,750 \pm 3606 \mathrm{cell} \cdot \mathrm{mL}^{-1}$ in $+1.7 \mathrm{Fe}$, all on the 8 th day of culture, and only $21,500 \pm 2186 \mathrm{cell} \cdot \mathrm{mL}^{-1}$ on the 11th day in the treatment with no Fe addition (Figure 3). Interestingly, the maximum cell density was even lower in the treatment that received the dissolved cell contents from a $P$. multiseries culture $(+1.7 \mathrm{Fe}+\mathrm{Psm})$, attaining only 16,200 cell $\cdot \mathrm{mL}^{-1}$ after 21 days in culture. Maximum cell densities were different among treatments ( $p=0.018$; one-way ANOVA), probably due to the lower values measured in $+1.7 \mathrm{Fe}+\mathrm{Psm}$, although the Student-Newman-Keuls (SNK) post-hoc test was not able to detect that (Supplementary Table S1). The highest exponential growth rate between days 0 and $8\left(\mu_{0-8}=0.41 \pm 0.05 \mathrm{~d}^{-1}\right)$ was measured in the treatment that received the greatest $\mathrm{Fe}$ addition $(+11,700 \mathrm{Fe})$. Within this same culture period, growth rates were significantly lower $\left(p=0.0006\right.$; one-way ANOVA) for the $+1.7 \mathrm{Fe}+\operatorname{Psm}$ treatment $\left(\mu_{0-8}=0.13 \pm 0.02 \mathrm{~d}^{-1}\right)$, and ranged from 0.28 to $0.36 \mathrm{~d}^{-1}$ for the other treatments (Table 1 and Table S1).

Surprisingly, the maximum growth rates of Bacillaria sp. $\left(\mu=0.80-1.25 \mathrm{~d}^{-1}\right)$ were consistently higher than those calculated for P. multiseries $\left(\mu=0.54-0.74 \mathrm{~d}^{-1}\right)$ in cultures with the addition of equivalent Fe concentrations, except for the $+1.7 \mathrm{Fe}+\mathrm{Psm}$ treatment $\left(\mu=0.36 \mathrm{~d}^{-1}\right)$ (Table 1). In all treatments, Bacillaria sp. formed chains, some containing more than 8 cells. However, there was a predominance of short chains, with 2 to 4 cells (Figure 3), similar to what was observed for P. multiseries. 

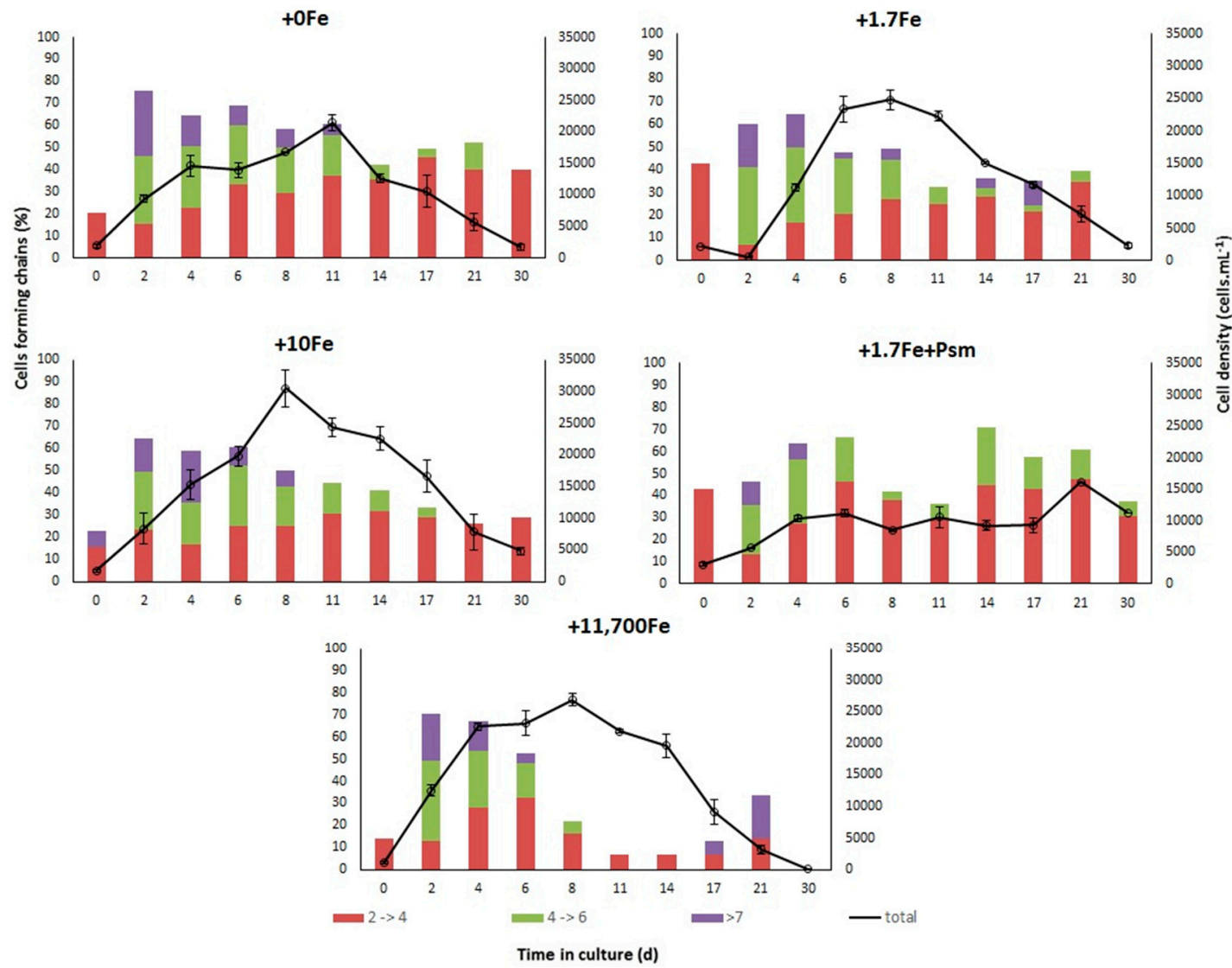

Figure 3. Average ( \pm standard error) cell density (solid line, $n=3$ ) and percentage of cells forming chains throughout the growth cycle of Bacillaria sp. in static cultures that received the addition of distinct iron concentrations: $+0 \mathrm{Fe} ;+1.7 \mathrm{Fe} ;+10 \mathrm{Fe}$; and $+11,700 \mathrm{Fe} \mathrm{nmol} \cdot \mathrm{L}^{-1}$. An extra treatment $(+1.7 \mathrm{Fe}+\mathrm{Psm})$ was created with the addition of $1.7 \mathrm{nmol} \mathrm{Fe} \cdot \mathrm{L}^{-1}$ and the dissolved cell contents from a $P$. multiseries culture containing $52 \mathrm{ng} \mathrm{DA} \cdot \mathrm{mL}^{-1}$ and other undetermined compounds. Colors of the stacked bars represent different cell chain lengths.

Similarly to P. multiseries, the relationship between Bacillaria sp. cell densities and experiment days for each $\mathrm{Fe}$ addition treatment was very strong (Deviance explained $=92 \%$; Figure 4 ). Expected densities reached maximum values at 8-11 days after the start of the experiment in all Fe treatments, except for the $+1.7 \mathrm{Fe}+\mathrm{Psm}$ treatment, where growth inhibition was observed at early stages. Shapes of the smoother curves, as well as the maximum expected density values, varied greatly among treatments (Figure 4). 

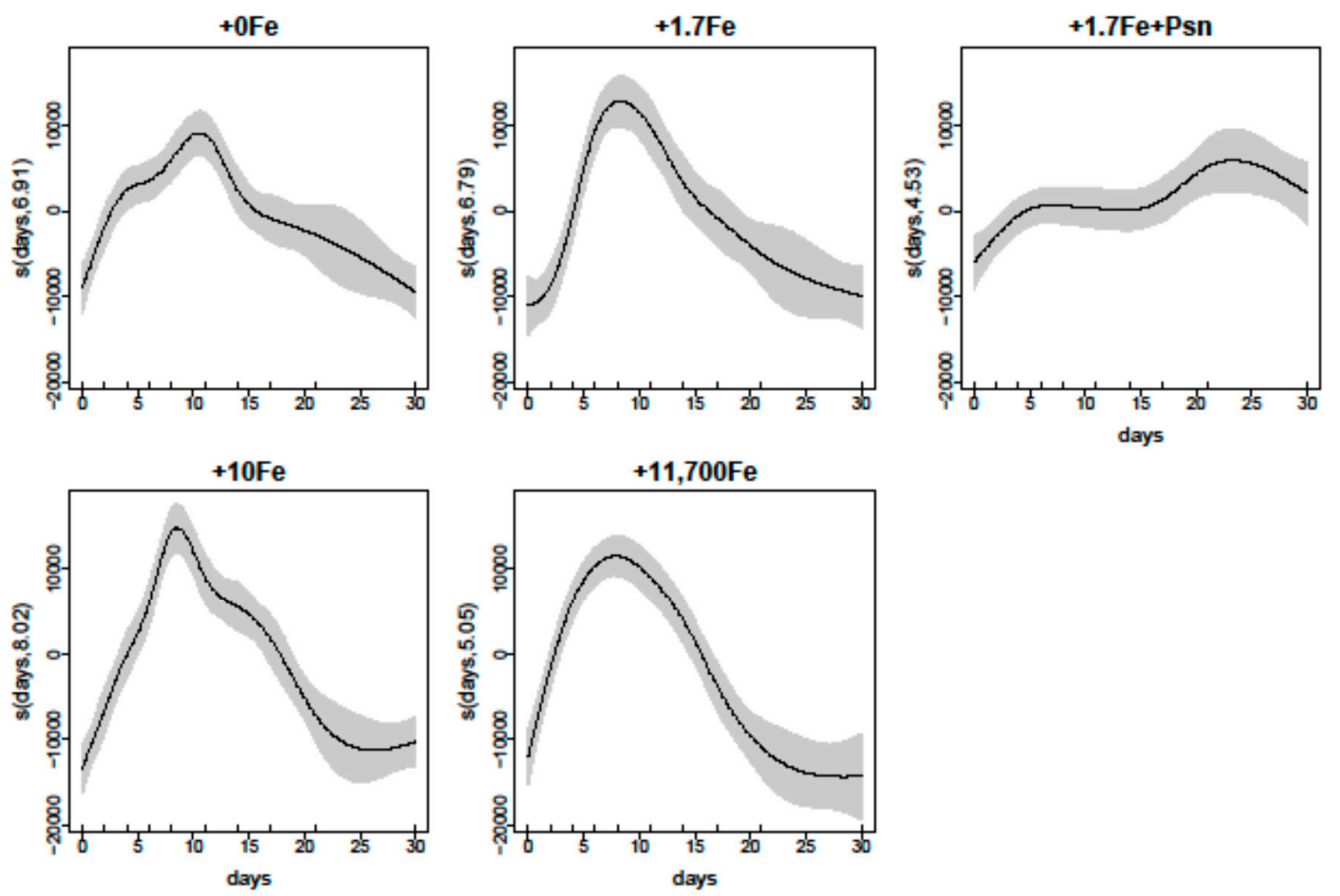

Figure 4. Estimated smoothing curves showing the relationship (solid line) between Bacillaria sp. densities and days for each Fe-enrichment treatment level: $+0 \mathrm{Fe}$; $+1.7 \mathrm{Fe}$; $+10 \mathrm{Fe}$; and $+11,700 \mathrm{Fe} \mathrm{nmol} \cdot \mathrm{L}^{-1}$, and an extra treatment $(+1.7 \mathrm{Fe}+\mathrm{Psm})$ with the addition of $1.7 \mathrm{nmol} \mathrm{Fe} \cdot \mathrm{L}^{-1}$ plus the dissolved cell contents from a culture of $P$. multiseries containing domoic acid at $52 \mathrm{ng} \cdot \mathrm{mL}^{-1}$ and other undetermined compounds. Shaded area represents the standard error of the smooth curve. The rug plots on the $x$-axis indicate the days measurements were taken. Numbers after the variable name on the $y$-axis represent estimated degrees of freedom.

\subsubsection{Chlorophyll- $a$}

The average chlorophyll- $a$ (chl- $a$ ) concentrations ranged from 0.35 to $341.2 \mu \mathrm{g} \cdot \mathrm{L}^{-1}$ over the experimental period and across all treatments, with the highest values recorded in treatment $+11,700 \mathrm{Fe}$ and the lowest ones in the treatment with no addition of Fe (Figure 5). Considering the two treatments that received the addition of the same iron concentration $\left(1.7 \mathrm{nmol} \cdot \mathrm{L}^{-1}\right),+1.7 \mathrm{Fe}$ and $+1.7 \mathrm{Fe}+\mathrm{Psm}$, chl- $a$ concentrations were usually lower in the latter, in which Bacillaria sp. cells were also exposed to the dissolved compounds from a P. multiseries culture (see Supplementary Table S3 for statistical results). In general, chl- $a$ concentrations followed the same temporal variation as cell density, attaining the maximum values at late exponential growth phase (day 8 ) and the minimum ones at the end of the experiment (day 30 ), except for treatment $+1,7 \mathrm{Fe}+\mathrm{Psm}$, in which values increased at slower rates, but constantly over time (Figures 4 and 5).

Considering the chl- $a$ concentration on a per cell basis, intracellular concentrations were significantly higher in treatment $+11,700 \mathrm{Fe}$, attaining up to $12.7-13.1 \mathrm{pg} \cdot \mathrm{cell}^{-1}$ during the exponential growth phase, and there were no significant differences among the average values measured in the other treatments (2.3-8.4 $\mathrm{pg} \cdot \mathrm{cell}^{-1}$ ) (Figure 5 and Table S2). 

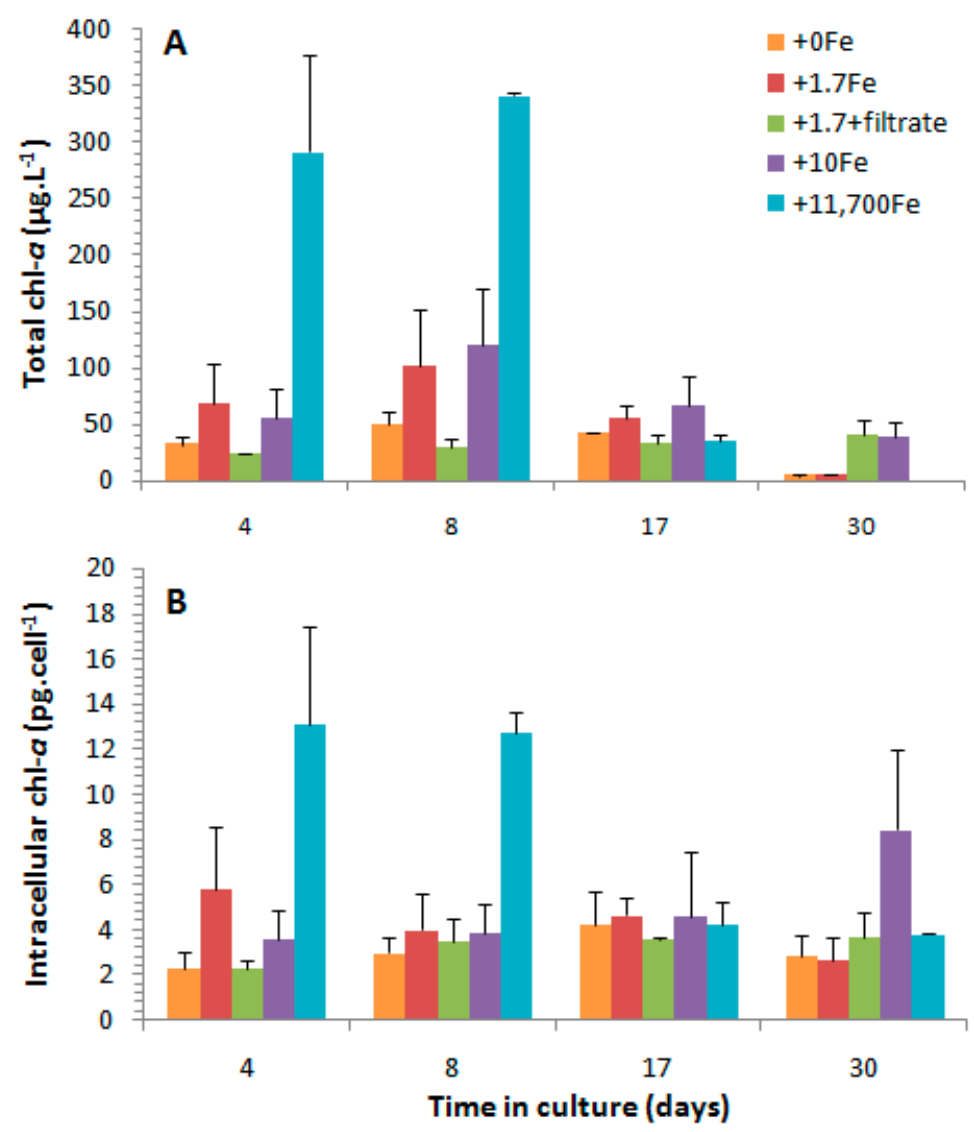

Figure 5. Total (A, $\left.\mu \mathrm{g} \cdot \mathrm{L}^{-1}\right)$ and intracellular (B, pg. cell $\left.{ }^{-1}\right)$ chlorophyll- $a$ (chl- $a$ ) concentrations (average \pm standard deviation, $n=2$ ) throughout the growth cycle of Bacillaria sp. in cultures that received the addition of distinct iron concentrations $\left(\mathrm{nmol} \cdot \mathrm{L}^{-1}\right)$ : $+0 \mathrm{Fe} ;+1.7 \mathrm{Fe} ;+10 \mathrm{Fe}$; and $+11,700 \mathrm{Fe}$ and the extra treatment $(+1.7 \mathrm{Fe}+\mathrm{Psm})$ with the addition of $1.7 \mathrm{nmol} \cdot \mathrm{Fe} \cdot \mathrm{L}^{-1}$ and the dissolved cell contents from a P. multiseries culture containing $52 \mathrm{ng} \mathrm{DA} \cdot \mathrm{mL}^{-1}$ and other undetermined compounds.

\section{Discussion}

\subsection{Effects of Fe-Enrichment on the Growth of P. multiseries and Bacillaria sp.}

The $P$. multiseries strain tested in this study reached similar cell densities and exponential growth rates in cultures exposed to different levels of Fe-enrichment. Similar results have been previously reported for a different $P$. multiseries isolate in cultures containing 0,120 , or $11,700 \mathrm{nmol} \cdot \mathrm{Fe} \cdot \mathrm{L}^{-1}$ [24]. In both studies, P. multiseries exhibited no signs of growth limitation by Fe shortage in static cultures, even when no iron was added to the Fe-depleted medium. In our experiment, only very limited, trace amounts of Fe must have been available in the $+0 \mathrm{Fe}$ treatment, transported both intra- and extra-cellularly with the inoculum, even after successive generations of culture acclimation under low concentrations of trace metals.

P. multiseries must, therefore, possess a very effective adaptation to limiting Fe conditions, as already indicated by Wells et al. [10] in another laboratory study. Accordingly, Pseudo-nitzschia spp. exhibited the most efficient physiological acclimation under low-Fe availability among the entire phytoplankton assemblage exposed to decreasing Fe concentrations in the Antarctic Peninsula [31].

Besides the lack of growth inhibition, there was no apparent effect of $\mathrm{Fe}$ availability on chain formation by P. multiseries cells in the present study. The length of linear chains of cells, i.e., the number of cells composing the chain, may vary according to the diatom species and be related to the turbulence and/or physiological state of the cells. As indicated by Lelong et al. [12], P. multiseries cells growing exponentially under replete nutrient conditions form longer chains, which become 
shorter and eventually detach into single cells as growth is limited during stationary phase. Thus, the similar incidence and length of P. multiseries stepped cell chains among the treatments in our experiment also indicate that the cultures were not growth-inhibited under any condition.

For Bacillaria sp., both the total chl-a concentrations (ng. $\mathrm{mL}^{-1}$ ) and the intracellular chl-a contents $\left(\mathrm{pg} \cdot \mathrm{cell}^{-1}\right)$ were much higher in the cultures that received the greatest Fe addition $\left(11,700 \mathrm{nmol} \cdot \mathrm{L}^{-1}\right)$, especially during the exponential growth phase. However, even though Bacillaria sp. cells had a lower photosynthetic capacity under lower concentrations of $\mathrm{Fe}$, chain formation, as well as the maximum cell densities and growth rates, were surprisingly comparable among the experimental treatments. This indicates that, similar to P. multiseries, Bacillaria sp. also exhibited an efficient mechanism of adaptation to low Fe conditions.

The mechanisms and strategies explaining the efficient adaptation of P. multiseries and Bacillaria sp. to low Fe concentrations are not fully comprehended. Sarthou et al. [32] suggested that cell size reduction may provide diatoms with an adaptive advantage under limiting Fe concentrations. Reducing the Fe demand for cellular growth-and consequently the $\mathrm{Fe}: \mathrm{C}$ ratio-may represent another strategy. In order to achieve that, diatoms might minimize the metabolic pathways that require greater Fe amounts, replace Fe-containing proteins with alternate ones containing different metals in their structures, or more efficiently use their Fe cell quotas [32]. During periods of high Fe availability, some coastal diatoms may store exceeding amounts of Fe at 20-30-fold greater $\mathrm{Fe}: \mathrm{C}$ ratios than necessary for maximum cell growth [32]. Furthermore, certain pennate diatoms, including Pseudo-nitzschia species, contain ferritin, an Fe-concentrating protein that allows the cells to store Fe under periods of intermittent availability [33]. This protein is presumably related to the chloroplasts, regulating the distribution and storage of Fe, which would ultimately assure the proper functioning of the photosynthetic apparatus [34]. In addition to the above mentioned adaptive strategies, toxigenic Pseudo-nitzschia species may hypothetically use DA as a trace metal chelator. The fraction of toxin released into the water would, therefore, facilitate the acquisition of Fe at low concentrations [12], as further discussed in Section 3.2.

\subsection{Effects of Fe-Enrichment on Toxin Production by P. multiseries}

There was an increase in both intra- and extracellular DA concentrations during and after the stationary growth phase of our P. multiseries cultures. For the most toxigenic Pseudo-nitzschia species, including $P$. multiseries, an inverse relationship between toxin synthesis and cell division rate is usually reported over the growth cycle, with maximum intracellular and extracellular DA levels attained when growth is arrested at stationary and decline phases, respectively [12,35]. The occurrence of higher intracellular DA contents in our study at decline phase-and not stationary phase, as usual (e.g., [36]) — may be due to a methodological artifact, since we only considered visibly living cells (i.e., with apparent chloroplasts) in our calculations of intracellular toxin levels.

In the present study, the highest intracellular DA concentrations were measured in the treatment that received the greatest addition of iron $\left(+11,700 \mathrm{nmol} \cdot \mathrm{L}^{-1}\right)$. Similarly, in another culture study with P. multiseries [24], total DA production increased up to 10-fold in cultures with high-Fe concentrations $\left(11,700 \mathrm{nmol} \cdot \mathrm{L}^{-1}\right)$ during the stationary growth phase, relative to low-Fe conditions (addition of 0-120 nmol. $\mathrm{L}^{-1}$ ). The authors postulated that Fe-stressed cells reduced their capacity to acquire nitrogen, which is essential for DA biosynthesis [24].

The levels of extracellular DA in our P. multiseries cultures, in contrast, were not consistently affected by the amount of iron added to the medium. The highest concentrations were measured in the treatment that received the greatest Fe addition during the stationary phase, and in the treatment with no Fe addition during the decline phase. Variations in the concentration of dissolved DA may result from an intricate balance between high photodegradation rates [37] and shifts in the rates of toxin release by the cells, which, in turn, are affected by differential cell death.

Maldonado et al. [25], in contrast, measured higher intra- and extracellular DA levels in Fe-limited cultures relative to an Fe-sufficient condition. According to the authors, DA production and release 
by Pseudo-nitzschia spp. could be a response to the stress caused by either lack of Fe or excess of Cu. The efficient adaptation of toxigenic Pseudo-nitzschia cells to Fe-limiting conditions would be therefore associated with the production and release of DA, which would be triggered under Fe privation [10]. Unfortunately, we could not reach the growth-limiting condition necessary to cause stress due to the lack of Fe in our study, even in the treatment with no addition of Fe.

The apparent contrasting results reported by Bates et al. [24] and Maldonado et al. [25] are not directly comparable though, since they measured the toxin concentrations in distinct culture fractions and were obtained from cultures at different growth phases (Table 3), as already noted by Lelong et al. (2012) [12]. In the present study, growth and DA production were evaluated over the entire growth cycle of a P. multiseries strain subjected to different Fe-enrichment conditions, and the toxin content was measured in both the particulate (intracellular) and dissolved (extracellular) culture fractions.

Table 3. Summary of results obtained by this and previous studies on the particulate (P, intracellular), dissolved ( $\mathrm{D}$, extracellular), and total $(\mathrm{T}=\mathrm{P}+\mathrm{D})$ domoic acid concentrations $\left(\mathrm{pg} \cdot \mathrm{cell}^{-1}\right.$ ) produced by Pseudo-nitzschia multiseries during distinct growth phases in static cultures that received the addition of either low or high iron $(\mathrm{Fe})$ concentrations.

\begin{tabular}{|c|c|c|c|c|c|c|}
\hline \multirow[b]{2}{*}{ Exponential phase } & \multicolumn{3}{|c|}{ Low-Fe Addition $\left(0-1.7 \mathrm{nmol} \cdot \mathrm{L}^{-1}\right)$} & \multicolumn{3}{|c|}{ High-Fe Addition $\left(120-11,700 \mathrm{nmol} \cdot \mathrm{L}^{-1}\right)$} \\
\hline & $\mathbf{P}$ & D & $\mathrm{T}$ & $\mathbf{P}$ & D & $\mathrm{T}$ \\
\hline Maldonado et al. (2002) [25] & 0.07 & 1.8 & & 0.03 & 0.21 & \\
\hline Present study & 0.06 & $0.81-1.8$ & & 0.20 & 0.55 & \\
\hline \multicolumn{7}{|l|}{ Early stationary phase } \\
\hline Bates et al. (2001) [24] & & & 4.0 & & & $14-18$ \\
\hline Present study & 0.26 & $1.95-25.8$ & & 0.45 & 91.3 & \\
\hline \multicolumn{7}{|l|}{ Declining/late stationary phase } \\
\hline Bates et al. (2001) [24] & & & 5.0 & & & $22-46$ \\
\hline Present study & $0.84-1.21$ & $4.56-18.6$ & & 2.07 & 6.83 & \\
\hline
\end{tabular}

The highest concentrations of DA in the cultures that received the addition of the greatest Fe concentrations highlights that Fe is decidedly important for DA biosynthesis, as already noted by Bates et al. [24]. Likewise, Fe is essential to many metabolic processes that require electron transfer reactions, such as photosynthesis, respiration, and nitrogen assimilation [32].

\subsection{Effects of the Cell Contents from P. multiseries Cultures on Bacillaria sp.}

When the dissolved cell contents from a P. multiseries culture were added to one of the treatments which the diatom Bacillaria sp. was exposed to, there was a notable growth inhibition, as assessed by a very limited increase in both cell density and total chl- $a$ concentration over the growth cycle. Such growth inhibition must have been caused by a reduction in Fe availability, or, most likely, due to the allelopathic effect of an undetermined harmful compound produced by P. multiseries.

No growth inhibition was reported when either P. multiseries or DA was mixed in batch cultures with different flagellated phytoplankton species (Chrysochromulina ericina, Eutreptiella gymnastica, Karenia mikimotoi, Heterocapsa triquetra, Heterosigma akashiwo, Prorocentrum minimum, Prorocentrum micans, Pyramimonas propulsa, and Rhodomonas marina) in a previous study [38]. However, the presence of allelopathic effects may be species-specific. In a recent study [39], Pseudo-nitzschia pungens limited the growth of Akashiwo sanguinea, Chattonella marina, Phaeocystis globosa, Rhodomonas salina, and P. minimum, and two different strains of $P$. multiseries affected negatively the growth of A. sanguinea. Considering the ecologically relevant cell densities tested, the observed allelopathic effect would represent a competitive advantage for Pseudo-nitzschia spp. in the field, playing an important role in the formation and persistence of both natural blooms and those following artificial fertilization with iron in high-nutrient, low-chlorophyll (HNLC) regions [39].

Allelopathic effects may be even more potent when the inhibited phytoplankton species is exposed to algal culture filtrates (i.e., cell-free culture medium) rather than to algal co-cultures 
(i.e., with allelopathic cells present). For instance, the filtered fraction from a P. multiseries culture has reduced $30-50 \%$ of the dinoflagellate $A$. sanguinea cell density relative to the control condition [39]. Moreover, in marine environments, the nutrient limitation can further increase the production of allelochemicals by certain phytoplankton species and/or strengthen their adverse effects over other algal species [40]. In the present study, under low iron concentration $\left(+1.7 \mathrm{nmol} \cdot \mathrm{L}^{-1}\right.$ condition), the presence of dissolved compounds produced by P. multiseries, including $52 \mathrm{ng} \mathrm{DA} \cdot \mathrm{mL}^{-1}$ and other undetermined substances, reduced $50-70 \%$ of the cell density and $70-90 \%$ of the total chl- $a$ content (ng. $\mathrm{mL}^{-1}$ ) of Bacillaria sp. at early stationary growth phase. To the best of our knowledge, this is the first report of allelopathic inhibition of a diatom species by DA-producing Pseudo-nitzschia at ecologically relevant cell densities (i.e., $\sim 8700$ cell equivalent $\cdot \mathrm{mL}^{-1}$ ); massive blooms can reach up to $\sim 13,000$ cells $\cdot \mathrm{mL}^{-1}$ and $20 \mathrm{ng}$ of particulate DA. $\mathrm{mL}^{-1}$, for instance [5]. Moreover, although frequently found in plankton, Bacillaria spp. are typically benthic, which suggests a broad action mechanism for the allelopathic effect reported herein for P. multiseries.

\section{Material and Methods}

\subsection{Culture Establishment and Acclimation}

A toxic Pseudo-nitzschia multiseries strain, kindly provided by Monterey Bay Aquarium Research Institute-MBARI (Moss Landing, CA, USA), and a strain of Bacillaria sp. isolated from the Estuarine Complex of Paranaguá $\left(25^{\circ} 30^{\prime} \mathrm{S}, 48^{\circ} 25^{\prime} \mathrm{W}\right)$, southern Brazil, were used in the present study.

Prior to the experiment, cultures of $P$. multiseries were maintained for seven generations (i.e., successive inoculations) in $\mathrm{f} / 2$ medium [41], modified to only $5 \%$ of the standard concentration of trace metals and for two additional generations with no addition of trace metals. Similarly, cultures of Bacillaria sp. were maintained for two generations in $\mathrm{f} / 2$ medium with no addition of trace metals, in order to reduce Fe carryover when the inoculum (17\% of the total volume) was added to the experimental units, as described below.

\subsection{Growth and Domoic Acid Production Experiments}

Two similar, independent experiments were performed to assess the effects of increasing Fe concentrations on the growth and chain formation by P. multiseries (Experiment 1) and Bacillaria sp. (Experiment 2), as well as on DA production and release (Experiment 1 only) or pigment synthesis (Experiment 2 only). In addition, the effects of dissolved substances released by P. multiseries to the growth of an Fe-depleted Bacillaria sp. culture were also investigated in Experiment 2, as described below.

For both experiments, synthetic seawater was prepared using Ultrapure water (Mili-Q) and salts, according to the composition and concentrations of Aquil medium [42], and enriched with macronutrients following the $\mathrm{f} / 2$ formulation [41]. The artificial seawater was gently passed through glass columns filled with Chelex 100 ion exchange resin for removing eventual trace metals. Eighty-milliliter aliquots of the acclimated P. multiseries and Bacillaria sp. cultures in stationary growth phase were then added to $350 \mathrm{~mL}$ of the synthetic seawater and placed in $500 \mathrm{~mL}$ Erlenmeyer flasks. Each experimental unit was sterilized by microwave and cooled to room temperature. Subsequently, vitamins and EDTA-metal traces were added to the medium following the $f / 2$ specifications, except for Fe, which was added as Fe-EDTA solution at different amounts according to each experimental treatment, as follows: $1.7 \mathrm{nmol} \cdot \mathrm{L}^{-1}, 10 \mathrm{nmol} \cdot \mathrm{L}^{-1}$ and $11,700 \mathrm{nmol} \cdot \mathrm{L}^{-1}$ (namely " $+1.7 \mathrm{Fe}^{\prime}, "+10 \mathrm{Fe}$ " and " $+11,700 \mathrm{Fe}$ ", respectively). The last treatment corresponded to the standard concentration indicated for $\mathrm{f} / 2$ medium. Additionally, no iron was added to compose a fourth experimental treatment (" $\left.+0 \mathrm{Fe}^{\prime \prime}\right)$. Although precaution was taken to prevent contamination of the artificial seawater with $\mathrm{Fe}$, it is possible that the inoculum carried traces of $\mathrm{Fe}$, including intracellularly.

Four replicates were performed in individual flasks for each treatment of Experiment 1, and three replicates for Experiment 2. In the latter, an additional treatment ("+1.7Fe+Psm") was 
obtained by passing $240 \mathrm{~mL}$ of non-axenic P. multiseries cultures under stationary growth (mean cell density: 46,700 cells $\cdot \mathrm{mL}^{-1}$ ) through glass microfiber filters ( $25 \mathrm{~mm}$ diameter, $1.2 \mu \mathrm{m}$ nominal porosity); then placing the filters into $20 \mathrm{~mL}$ of synthetic seawater and disrupting the retained cells with a ultrasound probe; re-filtering the solution with a $0.22 \mu \mathrm{m}$ PTFE syringe filter to remove cell debris, and collecting the filtered fraction. A $6.66 \mathrm{~mL}$ aliquot of the filtered liquid was finally added to $343.34 \mathrm{~mL}$ of synthetic seawater, followed by the addition of $1.7 \mathrm{nmol} \mathrm{Fe} \cdot \mathrm{L}^{-1}$ and other nutrients at standard $\mathrm{f} / 2$ concentrations to compose each replicate flask of the $+1.7 \mathrm{Fe}+\mathrm{Psm}$ treatment. The resulting solution contained DA at $52 \mathrm{ng} \cdot \mathrm{mL}^{-1}$ and other undetermined substances originally contained in 8680 P. multiseries cells $\cdot \mathrm{mL}^{-1}$.

Experimental flasks were inoculated with $80 \mathrm{~mL}$ of homogenized, acclimated cultures of P. multiseries (Experiment 1) or Bacillaria sp. (Experiment 2) under early stationary growth. Experiments lasted for 30 days, during which static cultures were maintained in an illuminated microbiological incubator under the following controlled conditions: $18-19^{\circ} \mathrm{C}, 30-32$ salinity, photoperiod $12: 12 \mathrm{~h}$, and irradiance $\sim 140 \mu \mathrm{E} \cdot \mathrm{m}^{-2} \cdot \mathrm{s}^{-1}$. Samples $(10 \mathrm{~mL})$ were collected every $2-3$ days throughout the growth curve and preserved with Lugol's solution (1\%). Cell density (cells. $\mathrm{mL}^{-1}$ ) and the proportion of cells forming linear chains were measured by light microscope counting using a Sedgewick-Rafter chamber. Additionally, $30 \mathrm{~mL}$ samples were collected at 4, 8, 17, and 30 days following the beginning of the experiment, and gently passed through Whatman ${ }^{\circledR}$ GF/F glass microfiber filters ( $25 \mathrm{~mm}$ diameter, $0.7 \mu \mathrm{m}$ particle retention) to determine the concentration of intra- and extracellular DA in P. multiseries or chlorophyll-a in Bacillaria sp. cultures.

\subsection{Chemical Analysis}

\subsubsection{Domoic Acid}

Filters containing retained P. multiseries cells were exposed for $2 \mathrm{~min}$ to an ultrasound probe in order to break the cells and release the intracellular contents into $4 \mathrm{~mL}$ of $100 \% \mathrm{MeOH}$ (J.T. Baker ${ }^{\circledR}$, Trinidad and Tobago, 99.96\% purity). The solution was then passed through syringe filters (Millipore ${ }^{\circledR}$, $0.22 \mu \mathrm{m}$ pore) to remove cell debris and the liquid was transferred to a vial for determination of the particulate (intracellular) DA concentration. In parallel, filtrate samples $(30 \mathrm{~mL})$ were loaded on a C-18 SEP-PAK cartridge and washed with $5 \mathrm{~mL}$ of $100 \% \mathrm{MeOH}$. The concentrated solution $(6 \times$ concentration factor) was then recovered into a vial for determination of the dissolved (extracellular) DA concentration. Domoic acid quantification was performed by an external standard method with DA calibration solutions prepared by diluting certified reference material (IMB-NRC, Canada) in $100 \% \mathrm{MeOH}$ at 5, 10, 50, 100, 250, and $300 \mathrm{ng} \cdot \mathrm{mL}^{-1}$.

The DA analyses were performed by liquid chromatography coupled with ultraviolet detection (LC-UVD) in a Chromaster VWR Hitachi LC system attached to a photodiode 5430 detector, following the methodology described in Mafra et al. [43]. A RP-18 endcapped Purospher STAR C-18 column was used as solid phase and the mobile phase was composed of (A) water and (B) 100\% acetonitrile, both containing $0.1 \%$ trifluoroacetic acid (TFA). Injections of $80 \mu \mathrm{L}$ of freshly acidified samples $(0.1 \%$ TFA) were performed in gradient elution mode (from 5 to $25 \%$ B in 25 min, holding for 2 min and back to $5 \% \mathrm{~B}$ in $3 \mathrm{~min}$ ). Limits of detection (LD) and quantification (LQ) were statistically calculated from the formulas $\mathrm{LD}=\left[\left(3^{*} \mathrm{std}\right) / \mathrm{b}\right]$ and $\mathrm{LQ}=[10 * \mathrm{std} / \mathrm{b}]$, where "std" is the standard deviation of the peak area from repeated analysis $(n=5)$ of the minimum measured concentration of DA in a standard solution, and " $b$ " is the slope of the calibration curve [43].

Only living cells (i.e., with visible chloroplasts) were considered for the calculation of cell density and intracellular DA concentration over time, while the sum of live and dead cells was used for the calculation of extracellular DA concentration on a per cell basis. 


\subsubsection{Chlorophyll- $a$}

Filters containing Bacillaria sp. cells were cut into small pieces and transferred to dark centrifuge tubes containing $4 \mathrm{~mL}$ of $90 \%$ acetone (Qhemis ${ }^{\circledR}$, Jundiaí, SP, Brazil; HPLC/UV grade). Samples were maintained at $-12{ }^{\circ} \mathrm{C}$ for $24 \mathrm{~h}$ and then centrifuged at $1000 \times g$ for $5 \mathrm{~min}$. After attaining room temperature, $2 \mathrm{~mL}$ of the supernatant were transferred to a quartz cuvette and the chlorophyll- $a$ fluorescence was determined in a Trilogy Laboratory fluorometer (Turner Designs ${ }^{\circledR}$, San Jose, CA, USA) before and $90 \mathrm{~s}$ after the addition of $60 \mu \mathrm{L}$ of $0.1 \mathrm{~N} \mathrm{HCl}$ (Vetec ${ }^{\circledR}$, Duque de Caxias, RJ, Brazil), in order to account for the concentration of pheophytin- $a$ [44]. Chlorophyll- $a$ was quantified from an external calibration curve made of successive dilutions of the analytical standard (Sigma-Aldrich ${ }^{\circledR}$, Saint Louis, MO, USA) at 5167.0, 1033.4, 206.68, 41.34, and 8.27 $\mu \mathrm{g} \cdot \mathrm{L}^{-1}$.

\subsection{Data Treatment and Statistical Analysis}

Statistical analysis and plots were performed in R software [45]. A two-factor analysis of variance (ANOVA) was used to compare dissolved and particulate DA concentrations (extra- and intracellular fractions, respectively), among experimental treatments (" $\mathrm{Tr}$ ": fixed, four levels, $+0 \mathrm{Fe}$; $+1.7 \mathrm{Fe} ;+10 \mathrm{Fe}$; $+11,700 \mathrm{Fe}$ ) and sampling times; ("Tm": fixed, four levels, $4 ; 8 ; 17 ; 30$ days, crossed with treatments) in Experiment 1, and among $\operatorname{Tr}$ (fixed, five levels, $+0 \mathrm{Fe}$; $+1.7 \mathrm{Fe} ;+10 \mathrm{Fe} ;+11,700 \mathrm{Fe}$; $+1.7 \mathrm{Fe}+\mathrm{Psm}$ ) and Tm (fixed, four levels, 4; 8; 17; 30 days, crossed with treatments) in Experiment 2. For those terms in ANOVA that were found to be significant at $p<0.05$, means were compared using Student-Newman-Keuls (SNK) tests. Normality and homoscedasticity assumptions were verified using Shapiro-Wilk and Cochran tests, respectively, and data were transformed to $\ln (x+1)$ when necessary. ANOVAs and SNK tests were performed using package GAD [46] in R.

The maximum exponential growth rates $\left(\mu, d^{-1}\right)$ were determined for Experiment 1 and Experiment 2 by the formula $\mu=\left[\ln \left(\mathrm{n}_{1}\right)-\ln \left(\mathrm{n}_{0}\right)\right] /\left(\mathrm{t}_{1}-\mathrm{t}_{0}\right)$, where $\ln \left(\mathrm{n}_{1}\right)$ and $\ln \left(\mathrm{n}_{0}\right)$ are the natural logarithms of the cell densities (cell. $\mathrm{mL}^{-1}$ ) at the end $\left(t_{1}, d\right)$ and beginning $\left(t_{0}, d\right)$ of the exponential phase for each treatment. Additionally, in order to facilitate the comparison across all treatments, the exponential growth rate was also calculated between the days 0 and $8\left(\mu_{0-8}\right)$, when cells were still multiplying exponentially in all cultures. Exponential growth rates $\left(\mu_{0-8}\right.$ and $\left.\mu\right)$ and cell densities from both Experiment 1 and Experiment 2 were individually compared among experimental treatments using a one-factor ANOVA. Assumptions checks and post-hoc comparisons of means were conducted as described for the statistical analysis on DA concentrations.

Generalized additive models (GAMs) were adjusted for P. multiseries and Bacillaria sp. cell densities using culture days and treatments as explanatory variables. Models were fitted using penalized cubic regression splines [47] in the mgcv package [38] of the R language. Two candidate models were adjusted: (i) one including the interaction between days (numerical predictor) and treatments (categorical predictor); and (ii) one without the interaction between days and treatments. Models were compared by an $F$-test and goodness of fit was assessed using Akaike Information Criteria (AIC). For both P. multiseries and Bacillaria sp. cell densities, the model that included the interaction was a better fit. Graphical diagnostics obtained with the gam.check() command in mgcv were used for model validation, in accordance with Zuur et al. [47].

\section{Conclusions}

The results from a series of laboratory experiments presented herein highlighted the great ability of two pennate diatoms, the domoic acid-producing Pseudo-nitzschia multiseries and the non-toxic Bacillaria sp., to survive and grow under low concentrations of iron. Moreover, the present study was the first to investigate the effects of different iron concentrations on the production and release of DA over the entire growth cycle of Pseudo-nitzschia multiseries in static cultures. Our results indicate that Fe is important for DA synthesis, since higher intracellular amounts of DA were detected in the cultures that received the addition of higher iron concentrations. Finally, the growth of Bacillaria 
sp. was inhibited by the presence of dissolved compounds originating from a P. multiseries culture, indicating, for the first time, an allelopathic effect of compounds released by Pseudo-nitzschia on another diatom species.

Supplementary Materials: The following are available online at www.mdpi.com/1660-3397/15/10/331/s1, Table S1: Results of the analysis of variance (ANOVA) and SNK multiple comparison tests for cell density, growth rate between days 0 and 8 of culture $\left(\mu_{0-8}\right)$ and maximum growth rate $(\mu)$ of Pseudo-nitzschia multiseries and Bacillaria sp., Table S2: Results of the analysis of variance (ANOVA) and SNK multiple comparison tests for intraand extracellular domoic acid (DA) concentrations, Table S3: Results of the analysis of variance (ANOVA) and SNK multiple comparison tests for the total $\left(\mu \mathrm{g} \cdot \mathrm{L}^{-1}\right)$ and intracellular $\left(\mathrm{pg} \cdot \mathrm{cell}^{-1}\right)$ chlorophyll- $a$ concentrations in Bacillaria sp. cultures.

Acknowledgments: The authors extend their gratitude to Luís Antônio O. Proença, Mathias Alberto Schramm and Thiago A. Pereira, from the Federal Institute of Santa Catarina, for their valuable assistance with part of the HPLC analysis; to the Brazilian National Research Council (CNPq) and CAPES for the scholarships awarded to B.F.S. and L.M.d.C., respectively; and to the Funding Agency of Paraná State (Fundação Araucária) for the grant awarded to L.L.M.J. (Agreement 567/2014). This study was funded by CNPq (grant \# 610012/2011-8) through the Brazilian National Institute of Science and Technology-INCT-Mar-COI.

Author Contributions: All authors made substantial contributions to the work reported. Precisely, B.F.S., L.L.M.J., L.M.d.C. and E.d.C.M. conceived and designed the experiments; B.F.S. and L.M.d.C. performed the experiments and lab analyses; C.R.K. performed the HPLC analysis; B.F.S., L.L.M.J. and L.S.-N. analyzed the data; L.L.M.J. and E.d.C.M. supplied reagents/materials/equipment; B.F.S., L.L.M.J. and L.M.d.C. wrote the paper.

Conflicts of Interest: The authors declare no conflict of interest.

\section{References}

1. Bates, S.S.; Bird, C.J.; de Freitas, A.S.W.; Foxall, R.; Gilgan, M.; Hanic, L.A.; Johnson, G.R.; McCulloch, A.W.; Odense, P.; Pocklington, R.; et al. Pennate diatom Niztschia pungens as the primary source of domoic acid, a toxin in shellfish from eastern Prince Edward Island. Can. J. Fish. Aquat. Sci. 1989, 46, 1203-1215. [CrossRef]

2. Wright, J.L.C.; Boyd, R.K.; De Freitas, A.S.W.; Falk, M.; Foxall, R.A.; Jamieson, W.D.; Laycock, M.V.; McCulloch, A.W.; McInnes, A.G.; Odense, P.; et al. Identification of domoic acid, a neuroexcitatory amino acid, in toxic mussels from eastern Prince Edward Island. Can. J. Chem. 1989, 67, 481-490. [CrossRef]

3. Scholin, C.A.; Gulland, F.; Doucette, G.J.; Benson, S.; Busman, M.; Chavez, F.P.; Cordaro, J.; DeLong, R.; De Vogelaere, A.; Harvey, J.; et al. Mortality of sea lions along the central California coast linked to a toxic diatom bloom. Nature 2000, 403, 80-84. [CrossRef] [PubMed]

4. Lefebvre, K.A.; Silver, M.W.; Coale, S.L.; Tjeerdema, R.S. Domoic acid in planktivorous fish in relation to toxic Pseudo-nitzschia cell densities. Mar. Biol. 2002, 140, 625-631.

5. McCabe, R.M.; Hickey, B.M.; Kudela, R.M.; Lefebvre, K.A.; Adams, N.G.; Bill, B.D.; Gulland, F.M.D.; Thomson, R.E.; Cochlan, W.P.; Trainer, V.L. An unprecedented coastwide toxic algal bloom linked to anomalous ocean conditions. Geophys. Res. Lett. 2016, 43, 10366-10376. [CrossRef] [PubMed]

6. Rue, E.; Bruland, K. Domoic acid binds iron and copper: A possible role for the toxin produced by the marine diatom Pseudo-nitzschia. Mar. Chem. 2001, 76, 127-134. [CrossRef]

7. Kumar, K.P.; Kumar, S.; Nair, G.A. Risk assessment of the amnesic shellfish poison, domoic acid, on animals and humans. J. Environ. Biol. 2009, 30, 319-325. [PubMed]

8. SERGAS. Primeira Notificación de Intoxicación po la Biotoxina ASP en Galicia. Boletín Epidemiolóxico de Galicia. 1 August 2014, Volume 3. Número 16. Available online: https:/ /www.sergas.es/Saude-publica/ Documents/1590/Venres_Epidemioloxico_vol3_n16_20140801.pdf (accessed on 24 October 2017).

9. Hasle, G.R. Are most of the domoic acid-producing species of the diatom genus Pseudo-nitzschia cosmopolites? Harmful Algae 2002, 1, 137-146. [CrossRef]

10. Wells, M.L.; Trick, C.G.; Cochlan, W.P.; Hughes, M.P.; Trainer, V.L. Domoic acid: The synergy of iron, copper, and the toxicity of diatoms. Limnol. Oceanogr. 2005, 50, 1908-1917. [CrossRef]

11. Lundholm, N. Bacillariophyceae. IOC-UNESCO Taxonomic Reference List of Harmful Micro Algae. 2017. Available online: http:/ / www.marinespecies.org/hab (accessed on 25 August 2017).

12. Lelong, A.; Hégaret, H.; Soudant, P.; Bates, S.S. Pseudo-nitzschia (Bacillariophyceae) species, domoic acid and amnesic shellfish poisoning: Revisiting previous paradigms. Phycologia 2012, 51, 168-216. [CrossRef] 
13. Trainer, V.L.; Bates, S.S.; Lundholm, N.; Thessen, A.E.; Cochlan, W.P.; Adams, N.G.; Trick, C.G. Pseudo-nitzschia physiological ecology, phylogeny, toxicity, monitoring and impacts on ecosystem health. Harmful Algae 2012, 14, 271-300. [CrossRef]

14. Mafra, L.L., Jr.; Fernandes, L.F.; Proença, L.A.O. Harmful algae and toxins in Paranaguá Bay, Brazil: Bases for monitoring. Braz. J. Oceanogr. 2006, 54, 107-121. [CrossRef]

15. Bates, S.S.; Richard, J. Domoic acid production and cell division by Pseudo-nitzschia multiseries in relation to a light: Dark cycle in silicate-limited chemostat culture. Can. Tech. Rep. Fish. Aquat. Sci. 1996, 0, 140-143.

16. Fehling, J.; Davidson, K.; Bates, S.S. Growth dynamics of non-toxic Pseudo-nitzschia delicatissima and toxic $P$. seriata (Bacillariophyceae) under simulated spring and summer photoperiods. Harmful Algae 2005, 4, 763-769. [CrossRef]

17. Lundholm, N.; Hansen, P.J.; Kotaki, Y. Effect of $\mathrm{pH}$ on growth and domoic acid production by potentially toxic diatoms of the genera Pseudo-nitzschia and Nitzschia. Mar. Ecol. Prog. Ser. 2004, 273, 1-15. [CrossRef]

18. Doucette, G.J.; King, K.L.; Thessen, A.E.; Dortch, Q. The effect of salinity on domoic acid production by the diatom Pseudo-nitzschia multiseries. Nova Hedwig. 2008, 133, 31-46.

19. Hansen, L.R.; Soylu, S.Í.; Kotaki, Y.; Moestrup, Ø.; Lundholm, N. Toxin production and temperature-induced morphological variation of the diatom Pseudo-nitzschia seriata from the Arctic. Harmful Algae 2011, 10, 689-696. [CrossRef]

20. Bates, S.; de Freitas, A.S.W.; Milley, J.E.; Pocklington, R.; Quilliam, M.; Smith, J.C.; Worms, J. Controls on domoic acid production by the diatom Nitzschia punges $f$. multiseries in culture: Nutrients and irradiance. Can. J. Fish. Aquat. Sci. 1991, 48, 1136-1144. [CrossRef]

21. Pan, Y.; Subba Rao, D.V.; Mann, K.H.; Brown, R.G.; Pocklington, R. Effets of silicate limitation on production of domoic acid, a neurotoxin, by the diatom Pseudo-nitschia multiseries. I. Batch culture studies. Mar. Ecol. Prog. Ser. 1996, 131, 225-233. [CrossRef]

22. Martin-Jézéquel, V.; Calu, G.; Candela, L.; Amzil, Z.; Jauffrais, T.; Séchet, V.; Weigel, P. Effects of organic and inorganic nitrogen on the growth and production of domoic acid by Pseudo-nitzschia multiseries and P. australis (Bacillariophyceae) in culture. Mar. Drugs 2015, 13, 7067-7086. [CrossRef] [PubMed]

23. Ryan, J.; Kudela, R.; Birch, J.; Blum, M.; Bowers, H.; Chavez, F.; Doucette, G.; Hayashi, K.; Marin, R., III; Mikulski, C.; et al. Causality of an extreme harmful algal bloom in Monterey Bay, California during the 2014-2016 northeast Pacific warm anomaly. Geophys. Res. Lett. 2017, 44, 5571-5579. [CrossRef]

24. Bates, S.S.; Léger, C.; Satchwell, M.; Boyer, G.L. The effects of iron on Domoic Acid production by Pseudo-nitzchia multiseries. In Harmful Algal Blooms 2000, Proceedings of the 9th International Conference on Harmful Algal Blooms, Hobart, Tasmania, 7-11 February 2000; Hallegraeff, G.A., Blackburn, S.I., Bolch, C.J., Lewis, R.J., Eds.; IOC/UNESCO: Paris, France, 2001; pp. 320-323.

25. Maldonado, M.T.; Hughes, M.P.; Rue, E.L.; Wells, M.L. The effect of Fe and Cu on growth and domoic acid production by Pseudo-nitzschia multiseries and Pseudo-nitzschia australis. Limnol. Oceanogr. 2002, 47, 515-526. [CrossRef]

26. Fuentes, M.S.; Wikfors, G.H. Control of domoic acid toxin expression in Pseudo-nitzschia multiseries by copper and silica: Relevance to mussel aquaculture in New England (USA). Mar. Environ. Res. 2013, 83, 23-28. [CrossRef] [PubMed]

27. Withfield, M. Interactions between phytoplankton and trace metals in the ocean. Adv. Mar. Biol. 2001, 41, 3-128.

28. Wells, M.L.; Prince, N.M.; Bruland, K.W. Iron chemistry in seawater and its relationships to phytoplankton: A workshop report. Mar. Chem. 1994, 48, 157-182. [CrossRef]

29. Endo, H.; Youshimura, T.; Kataoka, T.; Suzuki, K. Effects of $\mathrm{CO}_{2}$ and iron avalilability on phytoplankton and eubacterial community compositions in the northwest subarctic Pacific. J. Exp. Mar. Ecol. 2013, 439, 160-175. [CrossRef]

30. Albrecht-Gary, A.M.; Crumbliss, A.L. Coordination chemistry of siderophores: Thermodynamics and kinetics of iron chelation and release. Met. Ions Biol Syst. 1998, 35, 239-327. [PubMed]

31. Russo, A.D.P.G.; Souza, M.S.; Mendes, C.R.B.; Jesus, B.; Tavano, V.M.; Garcia, A.E. Photophysiological effects of Fe concentration on diatom-dominated phytoplankton assemblages in the Antarctic Peninsula region. J. Exp. Mar. Biol. Ecol. 2015, 466, 49-58. [CrossRef]

32. Sarthou, G.; Timmermans, K.R.; Blain, S.; Tréguer, P. Growth physiology and fate of diatoms in the ocean: A review. J. Sea Res. 2005, 53, 25-42. [CrossRef] 
33. Marchetti, A.; Maldonado, M.T.; Lane, E.S.; Harrison, P.J. Iron requirements of the pennate diatom Pseudo-nitzschia: Comparison of oceanic (high-nitrate, low-chlorophyll waters) and coastal species. Limnol. Oceanogr. 2006, 51, 2092-2101. [CrossRef]

34. Marchetti, A.; Parker, M.S.; Moccia, L.P.; Lin, E.O.; Arrieta, A.L.; Ribalet, F.; Murphy, M.E.P.; Maldonado, M.T.; Armbrust, E.V. Ferritin is used for iron storage in bloom-forming marine pennate diatoms. Nature 2009, 457, 467-470. [CrossRef] [PubMed]

35. Bates, S.S.; Garrison, D.L.; Horner, R.A. Bloom Dynamics and Physiology of Domoic acid Producing Pseudo-nitzschia species. In Physiological Ecology of Harmful Algal Blooms; Springer: Heidelberg, Germany, 1998; pp. 267-292.

36. Pan, Y.; Bates, S.S.; Cembella, A.D. Environmental stress and domoic acid production by Pseudo-nitzschia: A physiological perspective. Nat. Toxins 1998, 6, 127-135. [CrossRef]

37. Bouillon, R.C.; Kieber, R.J.; Skrabal, S.A.; Wright, J.L.C. Photochemistry and identification of photodegradation products of the marine toxin domoic acid. Mar. Chem. 2008, 110, 18-27. [CrossRef]

38. Lundholm, N.; Hansen, P.J.; Kotaki, Y. Lack of allelopathic effects of the domoic acid-producing marine diatom Pseudo-nitzschia multiseries. Mar. Ecol. Prog. Ser. 2005, 288, 21-33. [CrossRef]

39. Xu, N.; Tang, Y.Z.; Qin, J.; Duan, S.; Gobler, C.J. Ability of the marine diatoms Pseudo-nitzschia multiseries and P. pungens to inhibit the growth of co-occurring phytoplankton via allelopathy. Aquat. Microb. Ecol. 2015, 74, 29-41. [CrossRef]

40. Granéli, E.; Hanses, P.J. Allelopathy in Harmful Algae: A Mechanism to Compete for Resources? In Ecology of Harmful Algae; Granéli, E., Turner, J.T., Eds.; Springer: Berlin/Heidelberg, Germany; New York, NY, USA, 2007; Volume 88, pp. 189-201, ISBN 978-3-540-32209-2.

41. Guillard, R.R.L. Culture of phytoplankton for feeding marine invertebrates. In Culture of Marine Invertebrate Animals; Smith, W.L., Chaley, H.H., Eds.; Plenum Press: New York, NY, USA, 1975; pp. 29-60.

42. Price, N.M.; Harrison, G.I.; Hering, J.G.; Hudson, R.J.; Nirel, P.M.V.; Palenik, B.; Morel, F.M.M. Preparation and Chemistry of the Artificial Algal Culture Medium Aquil. Biol. Oceanogr. 1989, 6, 443-461.

43. Mafra, L.L.; Léger, C.; Bates, S.S.; Quilliam, M.A. Analysis of trace levels of domoic acid in seawater and plankton by liquid chromatography without derivatization, using UV or mass spectrometry detection. J. Chromatogr. A 2009, 1216, 6003-6011. [CrossRef] [PubMed]

44. Arar, E.J.; Collins, G.B. Method 445.0 In Vitro Determination of Chlorophyll a and Pheophytin-a in Marine and Freshwater Algae by Fluorescence; U.S. Environmental Protection Agency, National Expossure Research Laboratory: Cincinnati, OH, USA, 1997.

45. R Core Team. R: A Language and Environment for Statistical Computing; R Foundation for Statistical Computing: Vienna, Austria, 2016.

46. Sandrini-Neto, L.; Camargo, M.G. GAD: An R Package for ANOVA Designs from General Principles. R Package Version 1.1.1. 2012. Available online: http://CRAN.R-project.org/package=GAD (accessed on 10 August 2017).

47. Zuur, A.F.; Ieno, E.N.; Walker, N.J.; Saveliev, A.A.; Smith, G. Mixed Effects Models and Extension in Ecology with R; Springer: New York, NY, USA, 2009.

(C) 2017 by the authors. Licensee MDPI, Basel, Switzerland. This article is an open access article distributed under the terms and conditions of the Creative Commons Attribution (CC BY) license (http://creativecommons.org/licenses/by/4.0/). 